\title{
Time for National Renewal: Australian adult literacy and numeracy as 'foundation skills'
}

\author{
STEPHEN BLACK AND KEIKO YASUKAWA
}

\section{Introduction}

Those working in the field of adult literacy and numeracy are currently anticipating changes in the near future as the federal government has flagged the development of a National Foundation Skills Strategy (Australian Government 2010). 'Foundation skills' is a term that has recently been suggested as a way of simplifying discussions about literacy and numeracy (Perkins 2009:8), and it has gained traction in various Australian national policy environments (e.g. Gillard 2009, Council of Australian Governments [COAG] Reform Council 2009, Australian Government 2010). Foundation skills appears to encapsulate adult language, literacy and numeracy, and more broadly, it may also include so-called employability skills such as communication and teamwork (Roberts and Wignall 2010:1). In this paper, our main focus is on the adult literacy and numeracy dimensions of what is needed in the policy renewal.

While there are no specific details available at this stage, the general focus of a new National Foundation Skills Strategy seems clearly evident. A strong and influential call for a new national strategy came from Skills Australia (2010), an organisation with a mandate to develop the nation's industry skills (see http://www.skillsaustralia.gov.au/about-us.shtml). Similar 'human capital' arguments supporting the development of adult literacy and numeracy skills have been presented recently by the Australian Industry Group (2010) and the COAG Reform Council (2009). Already, the federal government in its recent 2010 budget has allocated significantly increased funding for workplace and jobseeker literacy and numeracy programs which are designed primarily to contribute to economic skills development (Australian Government 2010). These initiatives are in line with a commissioned publication designed to inform national directions for adult literacy and numeracy which suggests that 'work-based and workfocused programs should feature strongly in future strategies' (Perkins 2009:31).

The purpose of this paper is not to undermine the primacy of the human capital underpinnings of a new National Foundation Skills Strategy. In the current highly competitive, globalised economy, it is to be expected that a new national strategy will build on the perceived advantages of skills 
development for productivity and international competitiveness that were promoted in the previous national policy some twenty years ago (the ALLP Australian Language and Literacy Policy, see Department of Employment, Education and Training 1991). However, we maintain that in the development of a new national strategy, there is more than one perspective on the rationale for investing in adult literacy and numeracy. Lo Bianco, in his address to the 2010 Australian Council for Adult Literacy Conference (http://www.acal.edu.au/2010conf/presentations.htm) reminded the audience that while the OECD has consistently taken the human capital argument for literacy and numeracy, UNESCO has focused on human rights. While there may be some tensions between the two perspectives, we argue that a new national strategy cannot ignore the diminution of rights of people with economic and social disadvantage that can occur by pursuing a human capital based agenda alone. In fact, increasing social inclusion is part of the mandate for the vocational education and training (VET) sector that has been flagged in the work of both the National VET Equity Advisory Council (NVEAC 2010) and Skills Australia (2010).

In this paper we highlight four dimensions of the adult literacy and numeracy field which we consider should be incorporated in a new strategy. We draw on recent work on social capital which has direct implications for social inclusion, but also for complementing the human capital rationale for adult literacy and numeracy. We link this work to calls for more cross-sectoral partnerships, and we then highlight an area of VET that should receive greater prominence in a national strategy, the integration of literacy and numeracy in the delivery of VET courses. Finally, we consider professional learning and partnerships with universities in adult literacy and numeracy, and how the field can be revitalised.

\section{Social capital}

Twenty years ago social capital did not feature in government thinking in relation to adult literacy and numeracy policy, but much has happened in the intervening years to change this. Adopting the Australian Bureau of Statistics (2004) definition for social capital to mean 'networks, together with shared norms, values and understandings which facilitate cooperation within or amongst groups', the concept is now seen to have considerable value in adult education and adult literacy and numeracy in particular. Social capital can be seen as a resource, along with other forms of capital, including human capital, that contributes to the socio-economic wellbeing of individuals and communities (Coleman 1988, Putnam 2000). Further, there is recognition at national and international levels that social capital, often in conjunction with human capital, can have an important part to play in the prosperity and well-being of nations (Productivity Commission 2003, OECD 2001). 
To date, studies relating adult literacy and numeracy with social capital have been relatively limited, but nevertheless significant in their implications. Falk (2001) was instrumental in demonstrating that social capital was implicated with adult literacy and numeracy provision. He argued, for example, that in jobseeker literacy programs the focus on developing employment skills may be insufficient to result in employment outcomes unless participants have the requisite social capital, including access to the right networks. Research by Balatti, Black and Falk (2006) demonstrated that there are significant social capital outcomes from accredited adult literacy and numeracy courses, and further, that the development of social capital, often in combination with human capital, has an impact on the socio-economic well being of individuals in areas such as health, education and learning, employment, and their social environment. Balatti, Black and Falk (2009) in a later study provided guidelines for a social capital approach to pedagogy that was likely to enhance the production of social capital outcomes. Such an approach included viewing students as members of networks and developing bonding, bridging and linking ties through drawing on existing networks and building new networks for participants.

Most of the above research focuses on the role of social capital at an individual level, but there is evidence in the broader adult learning research to demonstrate the positive role of social capital in the well-being of communities (Falk, Golding and Balatti 2000, Falk and Kilpatrick 2000, Kilpatrick, Field and Falk 2003).

We consider that the role of social capital in adult literacy and numeracy learning is sufficiently significant and established to warrant its recognition alongside human capital as a rationale for adult literacy and numeracy provision. Adult literacy and numeracy programs are not just about developing the technical skills of reading, writing and doing sums. These skills in themselves count for little unless they can be put to good use (for example, in employment), and it requires social processes (i.e. social capital) to enable this to happen. Elements of social capital such as how people identify themselves in relation to others, their levels of trust with others, how they work with others in various networks, and the number and type of networks people can live and work within, are significant and should be explicitly acknowledged and written into a new strategy. The literature sometimes presents human and social capital as a dichotomy, involving a choice to be made between one or the other, a form of vocational/social divide (Perkins 2009:31). We maintain, however, the two forms of capital are interrelated and that socio-economic well-being requires both forms of capital (Balatti, Black and Falk 2006). 


\section{Cross-sectoral partnerships}

Drawing on the concept of social capital and also integrated or embedded literacy and numeracy (see next section), Wickert and McGuirk (2005) argue the need for the field of adult literacy and numeracy to extend beyond formal learning sites to become engaged as partners with a whole range of social policy areas. Literacy and numeracy learning has a significant role to play in other sectors such as health, youth work, and welfare. To date, integrated literacy and numeracy has featured primarily in workplace and VET support programs, and has been slow to feature in these other social policy areas. There have been a number of local crosssectoral initiatives reported in the areas of health (Black, Innes and Chopra 2008), family literacy (Leske, Harris and Francis 2005), youth studies (Widin, Yasukawa and Chodkiewicz 2008) and aspects of community development (Black, Lucchinelli and Flynn 2006, Shore 2009), but these initiatives have been undertaken primarily with short term innovative funding from the federal government. These local partnerships are often difficult to sustain due to the absence of underpinning partnerships at the broader policy and funding levels.

Balatti, Black and Falk (2009:33) provide a visual representation (Figure 1) of vertical and horizontal partnerships at the macro, meso and micro organisational levels. Importantly, we argue that what is needed are partnerships at the macro, foundation level involving, for example, government departments and peak professional organisations, to provide the policy and funding framework to support and sustain the community level partnerships (meso level) and the micro level of interaction where the learning happens. Without these macro partnerships, the other partnership levels tend to be short term only.

To a large degree it is the absence of government support and funding that currently restricts the potential for productive partnerships in a number of key social policy sectors. In the area of health, for example, overseas in countries such as the United States (Anderson and Rudd 2006, California Health Literacy Initiative 2008, Hohn 2002 ) and Canada (Rootman and Gordon-El-Bihbety 2008) there are considerable 'health literacy' programs involving active partnerships between adult literacy and numeracy and health professionals. In Australia, there are few significant health literacy partnerships involving health and adult literacy and numeracy professionals, and the concept of health literacy is almost exclusively the domain of health professionals. Take the case of 'mental health literacy', where there is macro organisational level support (COAG 2006), which in turn has resulted in extensive mental health literacy programs (presented as 'Mental Health First Aid) being managed in local communities throughout Australia, but exclusively by a health organisation 
(Orygen Youth Health Research Centre, see www.mhfa.com.au). Through partnerships with adult literacy and numeracy professionals, health literacy programs can be informed by pedagogies that assist participants to manage the literacy and numeracy demands involved in accessing, interpreting and acting upon information and strategies for improving their health.

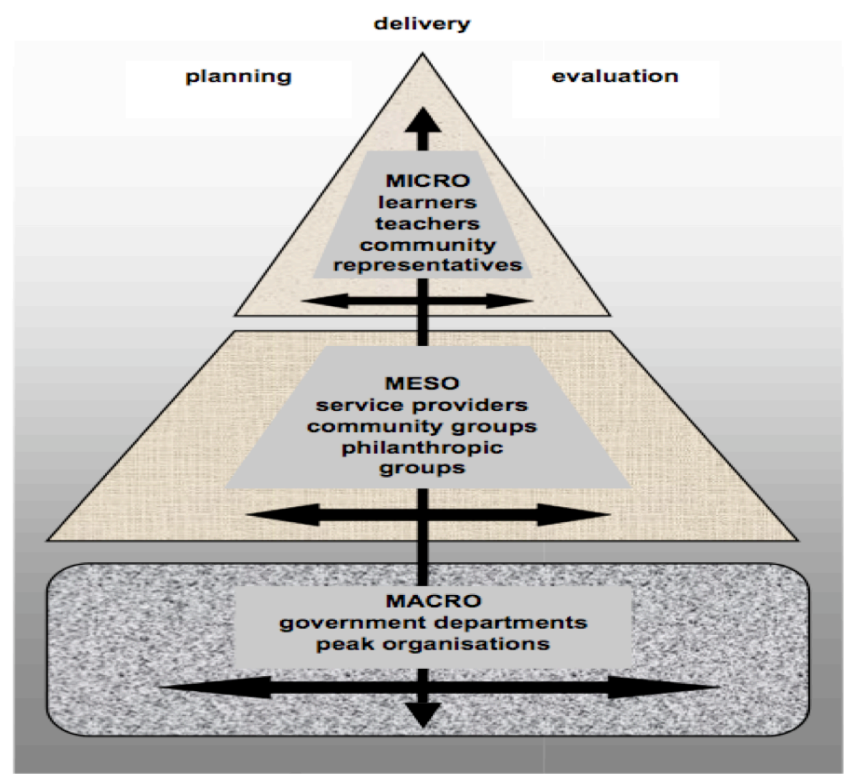

Figure 1: Partnership levels

Health is but one sector, though a key one, where there is considerable scope for partnerships involving both health and adult literacy and numeracy professionals. Low levels of health literacy are generally a strong indication of lower levels of health (Hartley and Horne 2006:7). As the Australian Bureau of Statistics (2008) 'health literacy' survey indicates, those with the lowest health literacy levels are often older, poorer, with lower formal education levels, with their first language not being English, and unemployed. These demographic characteristics fit the profile of many students in adult literacy and numeracy courses and thus their needs are well understood and addressed by literacy and numeracy teachers. The indications are that health and adult literacy and numeracy professionals 
work well together in partnership, especially in providing education for the prevention of chronic diseases such as type 2 diabetes (Black, Innes and Chopra 2008). Interestingly, health promotion professionals, like adult literacy and numeracy teachers, promote similar discourses of individual and community 'empowerment' (Lavarack 2007, World Health Organisation 1986)

Another area of potential cross-sectoral partnerships involves employers, unions and literacy and numeracy providers. Some of these partnerships have been enacted in Workplace English Language and Literacy (WELL) projects in terms of improved work skills, but not in terms of engaging workers in broader learning projects. In the UK for example, there are successful union learning representatives programs involving partnerships (Clough 2010, Alexandrou et al 2005) which are underpinned by literacy and numeracy support. These programs are funded largely through the UK government's Union Learning Fund, an example of the macro policy and funding foundation which is required for the sustainability of partnerships. New Zealand (Holland 2007) and other countries (e.g. Ireland, Denmark, Finland) have adopted union learning programs along similar lines.

At the national policy informing level there are strong calls by the NVEAC for cross-government, community and employer partnerships and for sustainable investments (NVEAC 2010:20,11) in light especially of stakeholder frustrations about short term and inconsistent funding. Australian adult literacy and numeracy researchers have strongly promoted the idea of partnerships in a number of sectors (Figgis 2004, Hartley and Horne 2006, Perkins 2009:33, Wickert and McGuirk 2005) and cross-sector representatives likewise have been receptive to such partnerships (e.g. Keleher and Hagger 2007 in relation to health). But without federal government policy and sustainable funding, partnerships will remain short term and ad hoc.

\section{Integrating literacy and numeracy in the delivery of VET courses}

In addition to literacy and numeracy programs conducted in workplaces (i.e. WELL - Workplace English Language and Literacy programs) and those that target the unemployed (i.e. the LLNP - the Language, Literacy and Numeracy Program), a further program area in need of federal government funding is one which involves the integration of literacy and numeracy in the delivery of the full range of VET courses. These programs have been a traditional focus of adult literacy and numeracy provision in public VET systems (e.g. Johnston 2002:25, Wickert et al 2007:251), often referred to as 'support' programs (as in Tutorial Support 
and Learner Support), but to date they have been funded primarily from state/territory budgets.

This type of program is based on the theoretical concept of the 'integration' of literacy and numeracy with vocational education and training, which involves concurrently developing literacy and numeracy and vocational skills and competences '... as interrelated elements of the one process' (Courtenay and Mawer 1995:2). In other words, literacy and numeracy are not taught as separate or discrete skills, but are contextualised or 'situated' within the process of learning vocational skills. In its practical application in VET, it often involves team teaching between literacy and numeracy teachers and vocational teachers, which has long been promoted as good practice in Technical and Further Education (TAFE) in New South Wales (e.g. Glossop 1990, Randazzo 1989), and is obligatory in the Certificate in Applied Vocational Study Skills (CAVSS) developed in Western Australia (Bates 2008). In most states and territories, there is a mixture of team teaching and withdrawing individuals or small groups of students in order to provide the additional literacy and numeracy support for them to complete their vocational studies.

Integrating literacy and numeracy in the delivery of VET courses has for many years worked effectively to improve workplace skills in the federal government's WELL program (Woods et al 2006). In a current research project (Black and Yasukawa forthcoming), interviews with VET teachers in different states and territories indicate that in college-based VET programs, the primary focus of these integrated programs is to provide support to enable students to complete what is often termed the 'theory' component of their vocational studies. This form of provision would appear to be basic to improving course completion rates and assisting the progress of students in VET, but nationally the extent of this provision is ad hoc, with funding levels and delivery methods varying considerably across the different states and territories.

While clearly this form of provision has implications for human capital development - including vocational knowledge, course completions and work skills, it has implications for social capital and social inclusion too. The new 'communities of practice' which vocational students are being apprenticed into, are new social networks with new sets of values, norms and behaviours involving bonding, bridging and linking ties to various other networks. For example, in one case study in a current research project (Black and Yasukawa forthcoming), multi-lingual literacy and numeracy students described their new peers as 'family', and several members of the group were actively planning to start a business together to serve the distinct needs of their ethnic communities.

Apart from acknowledgement that integrated literacy and numeracy support is needed and ought to be provided, there is little agreement or 
indeed debate, about the theoretical underpinnings of the pedagogies that are used. Further, with the exception of Western Australia, there is no designated funding for these programs, and therefore their funding is in competition with many other priorities in declining (in real terms) state VET budgets. Interestingly, the NVEAC (2010:13) has recently suggested in its blueprint for the future in VET that funding options should take account of 'foundation skills being embedded into VET delivery at all levels of the Australian Qualifications Framework'. Integrated literacy and numeracy delivery has been recognised overseas as an essential aspect of VET provision (e.g. Casey et al 2006, Hegarty and Feeley 2009) and is worthy of a national approach and funding. In fact, the case for such provision is stronger than ever given the recommendations arising from the Bradley Review of Australian Higher Education (2008) along with the COAG targets (COAG 2009) to increase the proportion of the Australian workforce holding university qualifications. Foundation skills can be seen to underpin courses that extend from VET to higher education level and the world of work beyond.

There are however, some cautionary notes to consider if integrated literacy and numeracy support is to join the workplace and jobseeker program initiatives currently funded by the federal government. Firstly, effective programs involving partnerships between adult literacy and numeracy teachers and those from vocational areas require additional investment costs in order to account for the shared planning, delivery and evaluation for continuous improvement (Casey et al 2006: 9, NVEAG 2010:20). These extra investment costs are unlikely to be compatible with the contestable funding model currently favoured by the federal government which, with its cyclical funding rounds, can lead to unsustainable provision. The NVEAC (2010:13) has recently drawn attention to the negative impact in VET of the contestable funding model.

A second cautionary note involves the casualisation of teachers. The investment in time and resources to make partnerships work between literacy and numeracy teachers and vocational teachers may be problematic when one or both categories of teachers are paid on a sessional/hourly basis. Necessarily, many part time/sessional teachers, by the very nature of their insecure employment, may have neither the time nor the inclination to invest their (often unpaid) time and energies into a partnership program where they can have their work terminated at very short notice (see Perkins 2009:34). The NVEAC (2010:17) reports that the high level of casualisation in VET is viewed as a critical issue for the VET workforce, and the employment status of teachers would appear to have an influence on the effectiveness of programs involving integrated delivery.

A final cautionary note involves the assessment of VET learners. Many vocational students, especially apprentices, are young, having left 
school fairly recently. They need literacy and numeracy support, but they may well resist and resent being identified as lacking or deficient in skills through the processes of receiving literacy and numeracy support. In the Western Australian CAVSS, the guidelines make clear that no students are assessed for their literacy and numeracy skills because the course is aimed at assisting the whole class (Bates 2008). While 'screening' to identify students in need of literacy and numeracy support is widespread in VET systems, less formal assessment methods which avoid a deficit approach to teaching and learning are likely to be more effective.

\section{Professional learning and partnerships with universities}

This final section considers the professional learning of adult literacy and numeracy teachers. It is a dimension of the adult literacy and numeracy field that has reached a parlous state and is badly in need of national renewal. This has been picked up in recent key publications (Skills Australia 2010, Roberts and Wignall 2010), and is beginning to be addressed through federal government initiatives, including a scholarship scheme to encourage and support initial teacher trainees in adult literacy and numeracy (Australian Government 2010). Alongside these initiatives are various projects examining aspects of workforce development, quality and qualification standards for the VET workforce more generally (Productivity Commission 2010, Wheelahan 2010, NVEAC 2010). Our main concern in this paper is the continuing professional learning of current adult literacy and numeracy teachers.

For the past decade or more, the mechanisms that have supported the professional learning of adult literacy and numeracy teachers in Australia have been crumbling. In the post-ALLP era (in particular the mid 1990s) there were many national professional development opportunities supported by the federal government via the National Staff Development Committee for Vocational Education and Training, but from this time onwards, at both federal and state levels, professional learning mechanisms have declined. National practitioner-based journals such as Good Practice in Adult Literacy and Basic Education and Literacy Now have come and gone. Organisations which provided resources and professional development, such as the Adult Literacy Information Office (ALIO) in Sydney (Johnston, Kelly and Johnston 2001), and the Adult Education Resource Information Service (ARIS) in Melbourne (Hazell 2002), have ceased operating and haven't been replaced. Through their regular publications (Broadsheet and ARIS Bulletin) both these organisations provided important national networks for professional learning. Other important information links through organisations such as Language Australia and the National Centre for Language Teaching Research (NCELTR) have also now ceased. The peak professional organisation for the field, the Australian Council for Adult Literacy (ACAL), 
contributes to professional learning with its annual conference, but the Council's longstanding newsletter, Literacy Link, has also now ceased publication through lack of funds.

Research in adult literacy and numeracy, which helps to inform the practitioner field, developed strongly for a short while with federal government support in the early 2000s with the Adult Literacy and Numeracy Australian Research Consortium (ALNARC). With the demise of ALNARC, continuing federal government research support was provided for a number of years via the National Centre for Vocational Education Research (NCVER), but this designated adult literacy research stream ceased from around 2007. Annual federal government Adult Literacy Innovative Projects funding also ceased at about the same time. Beyond the federal government's WELL and LLNP initiatives, there are now no national funding sources for research specifically in adult literacy and numeracy.

Many adult literacy and numeracy teachers have every reason to claim they are isolated, with few professional learning opportunities, and an almost complete absence of information about recent developments in the field (though the NCVER has made attempts to convey research findings to practitioners through their Adult Literacy Resource website, see http://www.adultliteracyresource.edu.au/). The NVEAC notes stakeholder concerns generally about access to professional development in VET (NVEAC 2010:17). In public VET Institutes, much of the current professional development initiatives seem to be focused not on pedagogy, but on compliance with accredited standards (see Black, this volume). It should be no surprise in the current climate to hear the following comment from an experienced adult literacy and numeracy teacher in a focus group:

We don't speak about pedagogy much, but I don't think anybody does either. I haven't seen new ideas around at all, reading theory, writing theory, what's new? Maybe it's there, but we're not seeing it. No professional development, no one speaks about pedagogy anymore (Black this volume).

And yet, while practitioners such as this teacher are asking 'what's new?', researchers are making claims about new 'paradigms' for adult literacy and numeracy studies (Balatti, Black and Falk 2009, Ivanic 2009:103). The research-practice nexus thus appears largely absent. What is needed is a re-focus on pedagogy and professional learning that goes beyond compliance with accredited standards. Adult literacy and numeracy teachers need a focal point, a national 'centre' where they can engage with ideas and theories, draw on recent developments in the field, and make a contribution themselves. A practitioner journal (which could be electronic) and a specific website should be available to all adult literacy and numeracy practitioners. The National Research and Development Centre (NRDC) for adult literacy 
in the UK, with its consortium of partners, provides a working model for such recommendations, though necessarily in Australia we may be talking of more modest proportions. Another area of need is practitioner research in adult literacy and numeracy, almost completely undeveloped in Australia, unlike in the UK (see Barton et al 2006, Davies, Hamilton and James 2007, Hamilton and Appleby 2009). This form of research would contribute not only to professional learning but to developing the capacity of the research community. The field of adult literacy and numeracy pedagogy appears to have has lost much of its vibrancy and enthusiasm. It needs re-energising.

The call for re-energising however, begs the question of who will lead and sustain it. The number of universities that focus on adult literacy and numeracy teacher development and research has never been large in Australia, but in recent years, the number has diminished further. While courses in TESOL feature in many universities, courses focused specifically on adult literacy and numeracy teaching are now almost invisible. The decline in these teaching programs has also meant a lack of renewal in the academic workforce who specialise in adult literacy and numeracy. Concomitant to developing practitioner research capacity therefore should be a program of academic renewal in adult literacy and numeracy so that the field has research partners in universities who can mentor practitioner researchers. Working together they can synthesise the research in the field and inject new theoretical constructs that can foster innovation and reflection. To facilitate this, teaching qualifications obtained in the university sector in adult literacy and numeracy that provide a pathway to a research degree program must be recognised as legitimate qualifications alongside VET qualifications in the field.

\section{Conclusions}

The field of adult literacy and numeracy in Australia stands at the cross roads. A new National Foundation Skills Strategy is an opportunity for renewal at a time of apparent decline. There are opportunities to develop further the important human capital rationale for adult literacy and numeracy provision, but also, as we have indicated, a social capital rationale which in turn complements skills development and enhances the socioeconomic well-being of individuals and communities. There are considerable opportunities for extending the influence and value of adult literacy and numeracy skills into other sectors with partnerships, but without national policy and subsequent sustainable funding, they will remain largely unfulfilled opportunities. And finally, those who work in the adult literacy and numeracy field, and for those who are new entrants, new opportunities and support mechanisms are urgently required for their professional learning and for re-building a sustainable and strong professional community. 


\section{References}

Alexandrou, A, Davies, JD and Lee, J (2005) Union Learning

Representatives: a case study of the Public and Commercial Services Union, Fournal of In-service Education, vol 31, no 1, pp9-25.

Anderson, J and Rudd, R (2006) Navigating Healthcare: Both educators and medical professionals have roles to play in making healthcare more accessible to all, Focus on Basics, vol 8, issue C, retrieved 2 September 2010 from http://www.ncsall.net/index.php?id=1156

Australian Bureau of Statistics (2004) Measuring Social Capital: An Australian framework and indicators, Information Paper 1378.0, ABS, Canberra.

Australian Bureau of Statistics (2008) Health Literacy, Australia, 2006, Information Paper 4233.0, ABS, Canberra.

Australian Government (2010) Budget 2010-11: Skills and infrastructurebuilding a stronger and fairer Australia, Australian Government, Canberra, retrieved 2 September 2010 from http://www.deewr.gov.au/Department/Budget/Documents/201011 BudgetMinisterialStatement.pdf

Australian Industry Group (2010) National Workforce Literacy Project: Report on employers' viewes on workplace literacy and numeracy skills, Australian Industry Group, North Sydney.

Balatti, J, Black, S and Falk, I (2006) Reframing Adult Literacy and Numeracy Outcomes: A social capital perspective, National Centre for Vocational Education Research, Adelaide.

Balatti, J, Black, S and Falk, I (2009) A Nerw Social Capital Paradigm for Adult Literacy: Partnerships, policy and pedagogy, National Centre for Vocational Education Research, Adelaide.

Bates, S (2008) Course in Applied Vocational Study Skills: Teacher's handbook, Western Australian Department of Education and Training, Perth.

Barton, D, Appleby, Y, Hodge, R, Tusting, R and Ivanic, R (2006) Relating Adults' Lives and Learning: Participation and engagement in different settings, NRDG, London.

Black, S, Innes, G and Chopra, M (2008) Diabetes Literacy: A partnership approach to educating culturally and linguistically diverse people about the risks and prevention of type 2 diabetes, Northern Sydney Institute/Northern Sydney Central Coast Area Health Service, Sydney, retrieved 2 September 2010 from http://icvet.tafensw.edu.au/ezine/year_2009/feb/diabetes-literacyreport.pdf

Black, S, Lucchinelli, M and Flynn, M (2006) Community Volunteering: Towards a cross-sectoral model of integrated literacy provision, TAFE Northern Sydney Institute, North Sydney.

Black, S and Yasukawa, K (forthcoming) Working Together: Integrated literacy and numeracy in VET, University of Technology, Sydney. 
Bradley, D, Noonan, P, Nugent, H and Scales, B (2008), Review of Australian Higher Education: Final Report, Commonwealth of Australia, Canberra.

California Health Literacy Initiative (2008) retrieved 2 September 2010 from http://cahealthliteracy.org/resource_center.html

Casey, H, Olga, C, Eldred, J, Grief, S, Hodge, R, Ivanic, R, Jupp, T, Lopez, D, McNeil, B (2006) You wouldn't expect a maths teacher to teach plastering: Embedding literacy and language in post 16 vocational programmes the impact on learning and achievement, NRDC, London.

Clough, B (2010) The Origins, Role and Impact of Union Learning Representatives in the UK and other Countries, Unionlearn, London.

Coleman, J (1988) Social capital in the creation of human capital, American Fournal of Sociology, vol 94, Supplement S, 95-120.

Council of Australian Governments (COAG) Reform Council (2009) National Agreement for Skills and Workforce Development: Baseline performance report for 2008, COAG Reform Council, Canberra.

COAG (2006) National Action Plan on Mental Health 2006-2011, retrieved 2 September 2010 from http://www.coag.gov.au/coag_meeting_outcomes/2006-0714/docs/nap_mental_health.pdf

Courtenay, M and Mawer, G (1995) Integrating English Language, Literacy and Numeracy into Vocational Education and Training: A framework, Foundation Studies Training Division TAFE NSW, Sydney.

Davies, P, Hamilton, M and James, K (2007) Maximising the Impact of Practitioner Research: A handbook of practical advice, NRDC, London.

Department of Employment, Education and Training (1991) Australia's Language: The Australian language and literacy policy, Department of Employment, Education and Training, Canberra.

Falk, I (2001) Sleight of Hand: Job myths, literacy and social capital, in J. Lo Bianco and R. Wickert, eds, Australian Policy Activism in Language and Literacy, Language Australia, Melbourne, pp 203-220.

Falk, I, Golding, B and Balatti, J (2000) Building Communities: ACE, lifelong learning and social capital, Adult, Community and Further Education Board, Melbourne.

Falk, I and Kilpatrick, S (2000) 'What is social capital? A study of a rural community', Sociologia Ruralis, vol 1, no 40, pp.87-110.

Figgis, J (2004) Literate Australia: A whole life approach. Report No.1: taking literacy to fresh fields, Viewed 26 June 2008, retrieved 2 September 2010 from http://www.acal.edu.au/publications/reports/Jane $\% 20$ Figgis $\% 20 \mathrm{R}$ eport.pdf

Gillard, J (2009) Speech at the Big Skills Conference, Darling Harbour, Sydney, 5 March 2009, retrieved 2 September 2010 from http://www.ala.asn.au/images/document/Guillard_speech_March_ 2009.pdf 
Glossop, C (1990) Team Teaching in Carpentry and Joinery, Good Practice in Australian Adult Literacy and Basic Education, no 11, pp 14-17.

Hamilton, M and Appleby, Y (2009) Critical Perspectives on Practitioner Research: Introduction to the special edition, Studies in the Education of Adults, vol 41, no 2 pp 107-117.

Hartley, R and Horne, J (2006) Social and Economic Benefits of Improved Adult Literacy: Towards a better understanding, National Centre for Vocational Education Research, Adelaide.

Hazell, P (2002) And then there was one: Investigating ARIS, the Victorian Adult Education and Resource Information Service, ALNARC, Sydney.

Hegarty, A and Feeley, M (2009) Literacy-Friendly Further Education and Training: An exploration of the potential for a whole organisation approach to integrating language and literacy in further education and training in Ireland, National Adult Literacy Agency, Dublin.

Hohn, M (2002) Literacy, Health, and Health Literacy: State policy considerations, Focus on Basics, no 5, issue C, pp 20-25.

Holland, G (2007) The Union Movement and Literacy in New Zealand, Literacy Link, vol 7, no 2, pp 1-4.

Ivanic, R (2009) Bringing Literacy Studies into Research on Learning Across the Curriculum, in M. Baynham and M. Prinsloo eds, The future of Literacy Studies, Palgrove MacMillan, Basingstoke (UK).

Johnston, B (2002) Numeracy in the Making: Twenty years of Australian adult numeracy, ALNARC, retrieved 2 September 2010 from http://www.staff.vu.edu.au/alnarc/publications/02Johnston.pdf

Johnston, B, Kelly, S and Johnston, K (2001) The Rise and Fall of the NSW Literacy Information Office, ALNARC, Sydney.

Keleher, H and Hagger, V (2007) Health Literacy in Primary Health Care, Australian Fournal of Primary Health Care, vol 13, No 2, pp 24-30.

Kilpatrick, S, Field, J and Falk, I (2003) Social Capital: An analytical tool for exploring lifelong learning and community development, British Educational Research Fournal, vol 29, no 3, pp.417-33.

Lavarack, G (2007) Health Promotion Practice: Empowered communities, Open University, London.

Leske, A, Harris, N and Francis, L (2005) Families in Focus: Mobile literacy mentoring, DEST, Canberra.

National VET Equity Advisory Council (NVEAG) (2010) Equity Blueprint: Creating futures: Achieving potential through VET, TVET Australia, Melbourne.

OECD (2001) The Well-Being of Nations: The role of human and social capital, OECD, Paris.

Perkins, K (2009) Adult literacy and numeracy: Research and future strategy, NGVER, Adelaide.

Productivity Commission (2003) Social Capital: Reviewing the concept and its policy implications, Commission research paper, AusInfo, Canberra. 
Productivity Commission (2010) Vocational Education and Training Workforce: Issues paper, Productivity Commission, Canberra.

Putnam, D (2000) Bowling Alone: The collapse and revival of American community, Simon \& Schuster, New York.

Randazzo, S, 1989, Literacy Support in a Trade Course, Good Practice in Australian Adult Literacy and Basic Education, no 6 p.5.

Roberts, A and Wignall, L (2010) Briefing on Foundation Skills for the National VET Equity Advisory Council, TVET, Melbourne, retrieved 2 September 2010 from http://www.nveac.tvetaustralia.com.au/_data/assets/pdf_file/0005 /53807/Briefing_on_Foundation_Skills__final_version.pdf

Rootman, I and Gordon-El-Bihbety, D (2008) A vision for a Health Literate Canada: Report of the expert panel on health literacy, Canadian Public Health Association, Ottawa, retrieved 2 September 2010 from http://www.cpha.ca/uploads/portals/h-l/report_e.pdf

Shore, S (2009) Playford Literacies: Building literacy capacity in learning communities, retrieved 2 September 2010 from http://www.deewr.gov.au/Skills/Programs/LitandNum/LiteracyNe t/GeneralResources/Documents/PlayfordLiteracies-FinalReport.pdf

Skills Australia (2010) Australian Workforce Futures: A national workforce development strategy, Commonwealth of Australia, Canberra.

Wheelahan, L (2010) Study on the Quality of Teaching in VET, Australian College of Educators, Melbourne, retrieved 2 September 2010 from https://austcolled.com.au/announcement/study-quality-teaching-vet

Wickert, R and McGuirk, J (2005) Integrating Literacies: Using partnerships to build literacy capabilities in communities, NGVER, Adelaide.

Wickert, R, Searle, J, Marr, B and Johnston, B (2007) Opportunities, Transitions, and Risks: Perspectives on adult literacy and numeracy development in Australia, retrieved 2 September 2010 from http://www.ncsall.net/fileadmin/resources/ann_rev/rall_v7_ch8.pd f

Widin, J, Yasukawa, K and Chodkiewicz, A (2008) Making Connections: Adult literacy and numeracy practices, Commonwealth of Australia, Sydney.

Woods, D, Gully, M, Bowman, K, Hargreaves, J, Harris, LA, Priest, S and Beddie, F (2006) Review of Literature: Workplace English language and literacy: Report prepared for Strategic Analysis and Evaluation Group, NCVER, Adelaide, retrieved 2 September 2010 from http://www.voced.edu.au/docs/dest/TD_TNC_89_714.pdf

World Health Organisation (1986) Ottawa Charter for Health Promotion, WHO, Ottawa, retrieved 2 September 2010 from http://www.who.int/hpr/NPH/docs/ottawa_charter_hp.pdf 